\title{
Peningkatan Pengetahuan Dan Ketrampilan Kelompok Tani Melalui Penerapan Paket Teknologi Tepat Guna Produksi Cabai Merah Di Lahan Masam
}

\author{
Catur Herison $^{1}$, Rustikawati ${ }^{2}$, Edhi Turmudi, Parwito ${ }^{3}$, Edi Susilo ${ }^{4}$ \\ ${ }^{1234}$ Universitas Bengkulu \\ Email: catur_herison@unib.ac.id
}

\begin{abstract}
Article History:
Received: April 2021

Revised: Juni 2021

Accepted: Juni 2021

Available online: Juni

2021
\end{abstract}

Kata Kunci: TTG, cabai merah, lahan masam

\begin{abstract}
Abstrak:
Petani pengelola lahan masam umumnya mengalami persoalan tidak mencu-kupinya hasil yang diperoleh karena produk-tivitas lahannya rendah. Keinginan petani untuk meningkatkan pendapatan melalui budidaya tanaman yang bernilai ekonomi tinggi,khususnya cabai merah terkendala keterbatasan pengetahuan dan ketrampilan dalam budidaya secara intensif. Kegiatan Pengabdian pada Masyarakat (PPM) ini bertujuan melakukan hilirisasi hasil penelitian kelompok peneliti Universitas Bengkulu dalam bentuk Paket Teknologi produksi cabai merah untuk membantu mengatasi permasalahan rendahnya produktivitas tanaman di lahan masam melalui peningkatan pengetahuan dan ketrampilan kelompok tani. Kegiatan PPM dilakukan dengan metode pelatihan berupa penyuluhan, praktek dan demonstrasi plot, di Kelompok Tani Bangun Jaya, Kelurahan Bentiring, Kecamatan Muara Bangkahulu, Kota Bengkulu, dan Kelompok Tani Melati Mekar Bersama, Desa Pekik Nyaring, Kecamatan Pondok Kelapa, Kabupaten Bengkulu Tengah. Berdasarkan evaluasi yang dilakukan, pelatihan paket teknologi budidaya cabai di ultisol dapat meningkatkan pengetahuan petani dalam pengelolaan lahan masam dan teknik budidaya cabai merah intensif. Metode penyuluhan dan demonstrasi plot efektif untuk menyampaikan tujuan kegiatan pengabdian pada masyarakat.
\end{abstract}




\section{Pendahuluan}

Wilayah pertanian di Kecamatan Muara Bangkahulu, Kota Bengkulu dan Kecamatan Pondok Kelapa, Kabupaten Bengkulu Tengah didominasi oleh jenis tanah Ultisol. Jenis tanah ini secara umum memiliki tingkat kesuburan rendah (Purwanto et al., 2020). Masyarakat tani di wilayah ini sebagian besar menghadapi masalah tidak mencukupinya hasil usahatani yang dilakukan untuk mencukupi kebutuhan keluarga. Usaha tanaman perkebunan seperti kelapa sawit, karet dan buah-buahan yang cocok pada taham masam, dalam skala lahan sempit, tidak dapat mencukupi kebutuhan hidup sehari-hari, apalagi kebutuhan pangan pokok harus dibeli. Sementara itu, tanaman lain yang diusahakan seperti terong, kacang panjang, ubi kayu memiliki daya hasil yang rendah

Berdasarkan hasil wawancara, anggota kelompok menyatakan berkeinginan untuk memanfaatkan lahan yang ada guna menambah pendapatan melalui produksi tanaman yang memiliki nilai ekonomi tinggi seperti tanaman cabai merah. Keinginan tersebut belum dapat diwujudkan karena keterbatasan pengetahuan dan ketrampilan dalam budidaya tanaman secara intensif.

Di sisi lain, rangkaian kegiatan penelitian tim peneliti Universitas Bengkulu terkait dengan solusi atas permasalahan tanah masam melalui perakitan varietas adaptif, maupun teknologi ameliorasi kapur, jenis dan dosis pupuk kandang, dosis dan cara aplikasi pupuk anorganik serta jarak tanam telah dilakukan. Hasil penelitian tersebut digunakan untuk memformulasikan Paket Teknologi Produksi Cabai Merah di Lahan Masam yang telah diuji di beberapa lokasi lahan masam (Herison et al., 2019). Paket Teknologi tersebut merupakan iptek dalam menjawab permasalahan petani tentang budidaya cabai merah pada tanah masam secara intensif. Melalui kegiatan hilirisasi penelitian, kerjasama sinergis antara masyarakat yang membutuhkan dengan institusi sebagai penyedia ipteks dapat diwujudkan. Novita \& Rahmawati (2017) menunjukkan bahwa hilirisasi penelitian dalam bentuk ipteks yang dihasilkan dapat membantu mengatasi permasalahan yang dihadapi petani. Tujuan kegiatan pengabdian ini adalah untuk melakukan hilirisasi hasil 
penelitian dalam bentuk Paket Teknologi produksi cabai merah untuk membantu mengatasi permasalahan rendahnya produktivitas tanaman cabai di lahan masam melalui peningkatan pengetahuan dan ketrampilan kelompok tani.

\section{Metode}

Kegiatan pengabdian pada masyarakat ini dilaksanakan pada bulan Juni sampai November 2020. Lokasi pengabdian di Kelurahan Bentiring, Kecamatan Muara Bangkahulu, Kota Bengkulu, dan di Desa Pekik Nyaring, Kecamatan Pondok Kelapa, Kabupaten Bengkulu Tengah. Kooperator dalam pelaksanaan pengabdian ini Kelompok Tani Bangun Jaya Kelurahan Bentiring dan Melati Mekar Bersama Desa Pekik Nyaring. Anggota dari masing-masing kelompok adalah sebanyak 20 orang petani. Kegiatan PPM ini dilakukan dalam bentuk penyuluhan dan demplot.

\section{Kegiatan Penyuluhan}

Kegiatan pengabdian pada masyarakat ini dilakukan dengan metode pelatihan secara terstruktur di kelompok tani sasaran berupa penyuluhan dan praktek dalam bentuk demonstrasi plot (demplot). Penyuluhan dimaksudkan untuk meningkatkan pengetahuan petani. Metode penyuluhan yang diikuti dengan tes evaluasi sangat efektif untuk meningkatkan pengetahuan kooperator seperti yang dilakukan oleh Harnisah et al. (2016).

Memperhatikan kondisi pandemi Covid19, teknik penyuluhan dilakukan dengan peserta 10 orang anggota kelompok tani, untuk menjaga jarak. Pada setiap kelompok tani dilakukan dua kali penyuluhan. Materi penyuluhan meliputi (1) karakteristik dan permasalahan lahan masam, serta cara pengelolaan untuk meningkatkan produktivitasnya dan (2) teknologi budidaya cabai merah intensif yang meliputi penyiapan lahan, pembibitan, penanaman, pemeliharaan tanaman, pengendalian hama dan penyakit. Materi tambahan dari mahasiswa Program Doktor Ilmu Pertanian adalah (1) aplikasi pupuk organik pada lahan masam dan (2) pengendalian virus kuning pada tanaman cabai.

Keberhasilan pelaksanaan program penyuluhan diukur berdasarkan 
hasil evaluasi pre dan post test. Seluruh peserta pelatihan dijadikan sebagai kooperator (responden) untuk mengisi quisioner evaluasi. Objek pengumpulan data adalah kooperator kegiatan pengabdian. Jumlah kooperator sebanyak 20 orang dan semuanya dijadikan sumber data primer. Data yang terkumpul selanjutnya dianalisis deskriptif dan komparasi antara sebelum dan sesudah kegiatan.

\section{Kegiatan Praktek dan demplot}

Kegiatan praktek sekaligus demonstrasi plot (demplot) dimaksudkan sebagai unjuk kerja penerapan setiap komponen TTG dalam produksi cabai merah di lahan masam. Petak percontohan demplot budidaya cabai merah secara intensif dilakukan pada lahan dengan luas $300 \mathrm{~m}^{2}$. Lokasi tersebut sekaligus digunakan sebagai praktek untuk meningkatkan ketrampilan petani dalam budidaya cabai merah intensif mengikuti TTG 'Produksi Cabai Merah di Lahan Masam'.

\section{Hasil}

\section{Kegiatan Penyuluhan}

Penyuluhan pertama, terkait dengan pemahaman dan manipulasi lahan ultisol di Kelompok Tani Bangun Jaya Desa Bentiring diikuti oleh anggota kelompok tani dengan menerapkan protocol kesehatan karena dilaksanakan disaat pandemic Covid 19. Tempat penyuluhan dilakukan di ruang terbuka agar terdapat sirkulasi udara yang lancar (Gambar 1). Penyuluhan Kelompok Tani Melati Mekar Bersama Desa Pekik Nyaring dilakukan di rumah ketua kelompok tani. Respon peserta sangat antusias yang ditunjukkan oleh banyaknya pertanyaan yang diajukan terkait permasalahan tanah ultisol. Pada sesi diskusi banyak pertanyaan tentang mengatasi kendala tanah masam. Mereka baru menyadari bahwa tanah masam mengandung unsur aluminium yang dapat meracuni tanaman.

Hasil evaluasi menunjukkan terdapat peningkatan pemahaman yang nyata pada sebagian besar topik yang ditanyakan pada anggota Kelompok Tani Bangun Jaya (Gambar 2). Dari tujuh kelompok pertanyaan, pertanyaan tentang status hara mineral tanah masam tidak ada yang menjawab dengan 
benar pada pre test. Bahkan setelah diberi penyuluhan, hanya $17 \%$ peserta yang menjawab benar. Aspek paling dipahami oleh peserta baik sebelum maupun setelah penyuluhan adalah tentang penyebab tanaman keracunan. Sebelum penyuluhan $67 \%$ jawaban benar dan setelah penyuluhan menjadi $83 \%$.

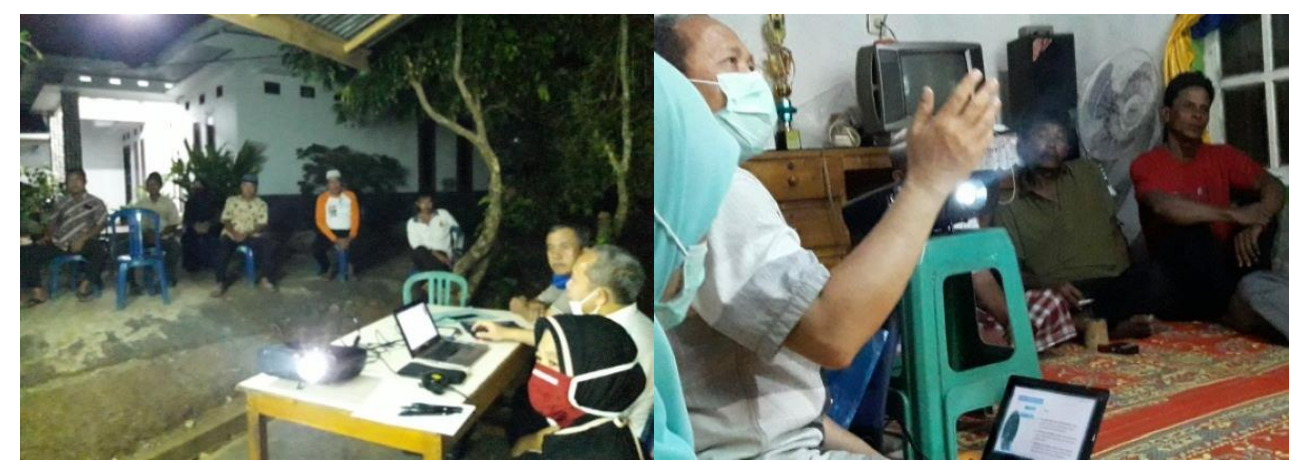

Gambar 1. Penyampaian materi dan diskusi tentang lahan masam pada Kelompok Tani Bangun Jaya (kiri) dan Melati Mekar Bersama (kanan)
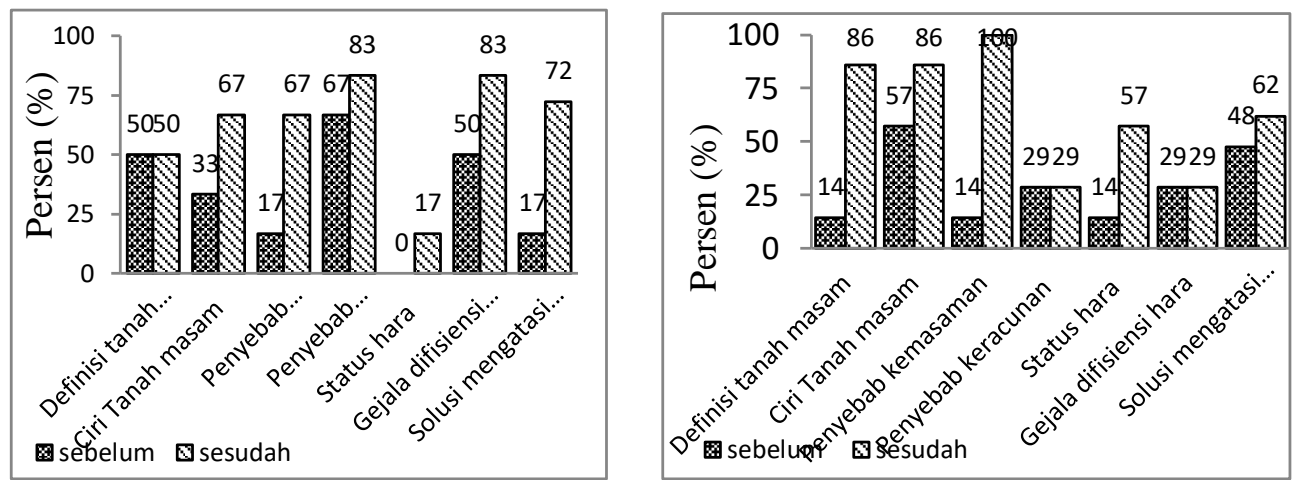

Gambar 2. Hasil penilaian pemahaman tanah masam terhadap anggota Kelompok Tani Bangun Jaya (kiri) dan Kelompok Tani Melati Mekar

Bersama (kanan) sebelum dan setelah penyuluhan

Kelompok Tani Melati Mekar Bersama menunjukkan pemahaman tentang tanah masam di bawah 50\% untuk hampir semua pertanyaan yang diberikan kecuali tentang ciri tanah masam. Antusiasme dalam mengikuti penyuluhan menyebabkan peningkatan pemahaman yang signifikan. Secara umum, kelompok tani Bangun Jaya lebih baik dalam menerima transfer ilmu 
dalam penyuluhan tentang tanah masam. Hal ini kemungkinan karena kelompok tani Bangun Jaya berada di wilayah kota yang relatif lebih sering mengikuti pelatihan dan akses terhadap informasi yang lebih baik dibandingkan dengan kelompok tani Melati Mekar Bersama yang tinggal di wilayah perdesaan.

Kegiatan penyuluhan kedua dilakukan terhadap kedua kelompok tani dengan materi budidaya tanaman cabai (Gambar 3). Penyuluhan pada kelompok tani Bangun Jaya dilakukan di rumah ketua kelompok dan diikuti 11 orang anggota. Penyuluhan di kelompok tani Melati Mekar Bersama dilakukan di rumah ketua kelompok dan diikuti 9 orang anggota. Semua anggota kelompok tani sudah pernah menanam cabai sehingga diskusi sangat aktif membahas permasalahan yang pernah mereka hadapi. Permasalahan yang menjadi topik yang banyak dibahas adalah terkait dengan organisme pengganggu tanaman, khususnya hama dan penyakit. Permasalahan tentang bagaimana menghadapi penyakit yang disebabkan oleh virus juga mengemuka dalam diskusi. Melalui kegiatan penyuluhan ini petani mendapat pengetahuan tentang jenis-jenis hama dan penyakit serta pengendaliannya. Peserta penyuluhan akhirnya memahami bahwa tidak semua penyakit dapat diatasi dengan penyemprotan pestisida.
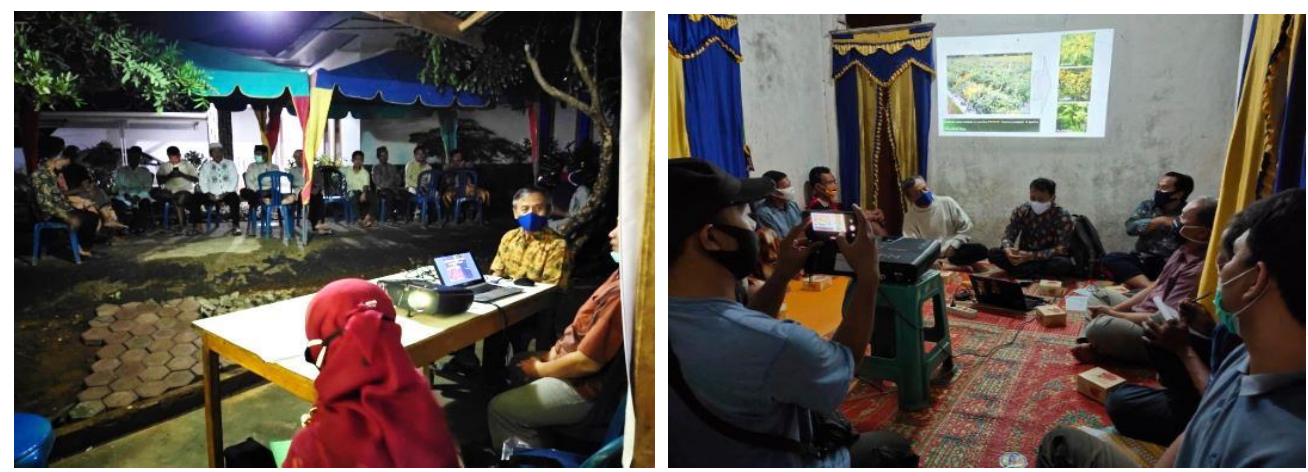

Gambar 3. Penyampaian materi dan diskusi tentang budidaya cabai pada Kelompok Tani Bangun Jaya (kiri) dan Melati Mekar Bersama (kanan) 
Evaluasi penyampaian materi penyuluhan menunjukkan bahwa pada kelompok tani Bangun Jaya terjadi peningkatan pengetahuan yang sangat nyata untuk hampir setiap aspek teknologi produksi cabai merah. Pengetahuan tentang karakteristik tanaman cabai merah, kebutuhan benih, jarak tanam, jenis dan dosis pupuk organik, dan cara pemberian dan jenis pupuk sintetis umumnya masih rendah. Akan tetapi, pengetahuan tentang perlakuan benih, cara pembibitan dan penyiapan lahan sudah cukup baik. Setelah kegiatan penyuluhan, pengetahuan tentang teknologi budidaya cabai yang intensif untuk lahan masam sudah dikuasai dengan baik. Untuk pengetahuan tentang cara pembibitan dan penyiapan lahan yang baik, lebih dari $90 \%$ responden dapat menjawab dengan benar (Gambar 4).

Pada kelompok tani Melati Mekar Bersama, pengetahuan tentang teknologi budidaya cabai secara intensif umumnya masih rendah, hanya pada aspek pengelolaan benih sebelum pembibitan dan penyiapan lahan yang cukup baik. Setelah kegiatan penyuluhan terlihat pada Gambar 4 bahwa terdapat peningkatan pemahaman yang sangat signifikan. Pada hampir seluruh aspek teknologi budidaya cabai merah sudah dapat dikuasai dengan baik. Bahkan pada aspek cara penyiapan lahan yang baik dan benar, serta penggunaan pupuk berimbang dalam takaran yang benar lebih dari $90 \%$ peserta dapat menjawab dengan benar.
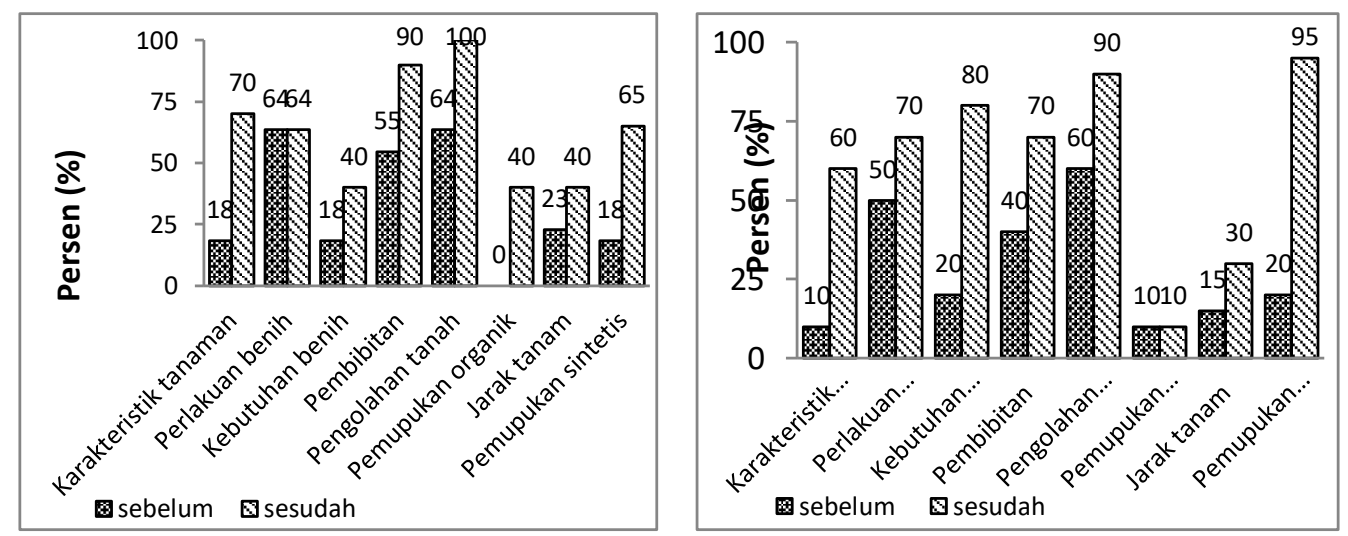

Gambar 4. Hasil penilaian pemahaman budidaya cabai terhadap anggota Kelompok Tani Bangun Jaya (kiri) dan Kelompok Tani Melati Mekar

Bersama (kanan) sebelum dan setelah penyuluhan 
Tingginya peningkatan pemahaman tentang aspek teknologi budidaya cabai merah secara intensif pada tanah masam di kedua kelompok tani tersebut mengindikasikan bahwa antusiasme peserta penyuluhan terhadap materi yang diberikan sangat tinggi. Sekalipun kegiatan dilakukan pada malam hari setelah berkegiatan rutin siang hari, peserta penyuluhan masih sangat antusias menyimak dan memperhatikan materi dengan baik. Selain itu, peningkatan pemahaman ini juga mengindikasikan bahwa cara penyampaian materi menggunakan alat bantu infocus dengan tayangan power point sederhana yang disertai dengan gambar-gambar sudah sangat baik dan mengena ke kelompok sasaran. Jumlah peserta yang terbatas juga menjadi faktor positif yang mendukung interaksi antara pemberi materi dengan peserta lebih intensif.

\section{Kegiatan Praktek dan Demplot}

Kegiatan praktek sekaligus demplot sebagai peragaan paket teknologi budidaya cabai merah di Desa Pekik Nyaring dilakukan di tengah areal persawahan Desa Pekik Nyaring bertujuan untuk memudahkan petani mengikuti kegiatan budidaya cabai merah. Lokasi demplot berdekatan dengan lokasi sawah anggota kelompok tani. Penyiapan lahan dilakukan oleh anggota kelompok tani dengan pengarahan pembuatan bedengan dan arah baris bedengan oleh pengabdi. Bibit cabai merah disemai pada tray pembibitan dan dipelihara hingga umur 30 hari setelah semai (Gambar 5).
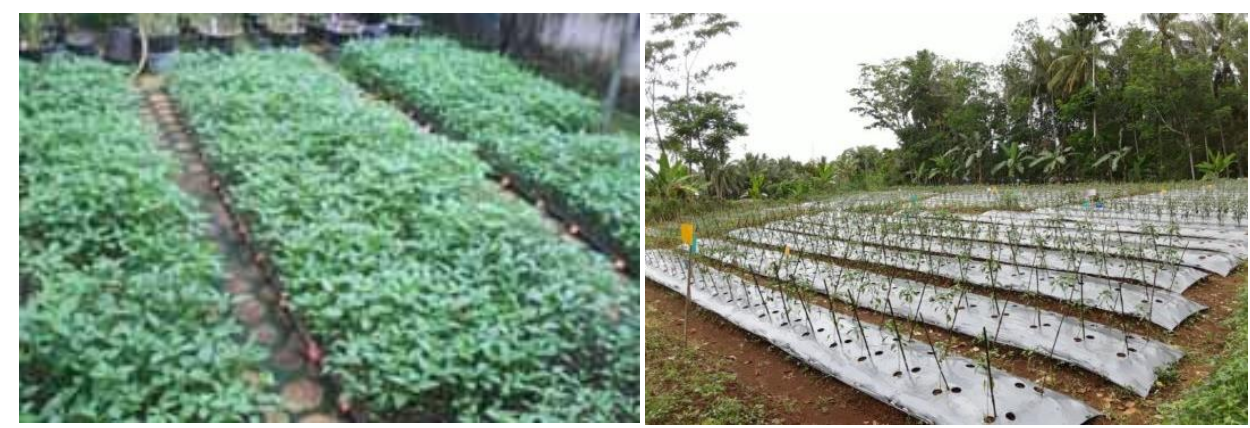

Gambar 5. Bibit siap tanam (kiri) dan lahan demplot yang sudah ditanami (kanan) di Desa Pekik Nyaring, Kecamatan Pondok Kelapa, Kabupaten Bengkulu Tengah 
Lahan disiapkan dalam bentuk bedengan lebar 1 meter dan panjang menyesuaikan lahan. Setelah dikapur dengan takaran $2 \mathrm{~kg} / \mathrm{m}^{2}$, dipupuk kandang $20 \mathrm{~kg} / \mathrm{m}^{2}$ dan pupuk dasar (urea $20 \mathrm{~g} / \mathrm{m}^{2}, \mathrm{SP} 3620 \mathrm{~g} / \mathrm{m}^{2}, \mathrm{KCl} 15 \mathrm{~g} / \mathrm{m}^{2}$ ) bedengan ditutup mulsa. Untuk menghindari efek terbakar pada leher akar, dibuat lubang ganda pada bedengan. Lubang pertama untuk pindah tanam bibit cabai, sedangkan lubang yang kedua untuk pemupukan sekaligus sebagai sirkulasi dari udara panas yang terbentuk di bawah mulsa (Gambar 5). Satu bedengan ditanam 2 baris dengan jarak antar baris $50 \mathrm{~cm}$ dan dalam barisan $40 \mathrm{~cm}$. Untuk mengurangi stress pada saat pindah tanam dilakukan pembumbunan pada bibit yang ditanam hingga menutup semua lubang pada mulsa. Perlakuan ini dapat menurunkan jumlah tanaman stress akibat pindah tanam hingga $80 \%$ jika intensitas cahaya sedang tinggi.

Kondisi tanaman pada panen pertama sangat bagus. Petani berdiskusi langsung di lahan membandingkan pertanaman hasil prakteknya dengan tanaman demplot. Pertanyaan dalam diskusi sebagian besar terkait virus kuning yang banyak menginfeksi pertanaman cabai di Desa Pekik Nyaring.

Kondisi pertanaman pada panen ke lima menunjukkan bahwa sekitar $20 \%$ tanaman mulai terserang virus kuning. Infeksi virus pada fase vegetatif lanjut mengurangi potensi produksi namun tanaman masih berproduksi yang layak secara ekonomi (Gambar 6). Pada panen ke lima jumlah cabai terinfeksi hanya di bawah 5\%. Namun kondisi cuaca yang panas dan lembab serta angin yang kencang memungkinkan spora cepat menyebar pada pertanaman lain. Pengendalian fungi menggunakan Score atau Dithane M 45 secara bergantian dengan interval 5 hari sekali berhasil dengan baik.

\section{Diskusi}

Ultisol mendominasi luasan lahan kering di Indonesia termasuk di Bengkulu. Berdasarkan penelitian yang dilakukan oleh Tarihoran (2013) dan Khotimah, et al. (2019), jenis tanah ini di wilayah Kecamatan Muara Bangkahulu bersifat masam. Hasil analisis tanah pada penelitian (Yanti, 2019) menunjukkan bahwa $\mathrm{pH}$ tanah di sekitar lokasi pengabdian adalah masam. Demikian halnya lahan di wilayah Pekik Nyaring, Kecamatan Pondok Kelapa. 

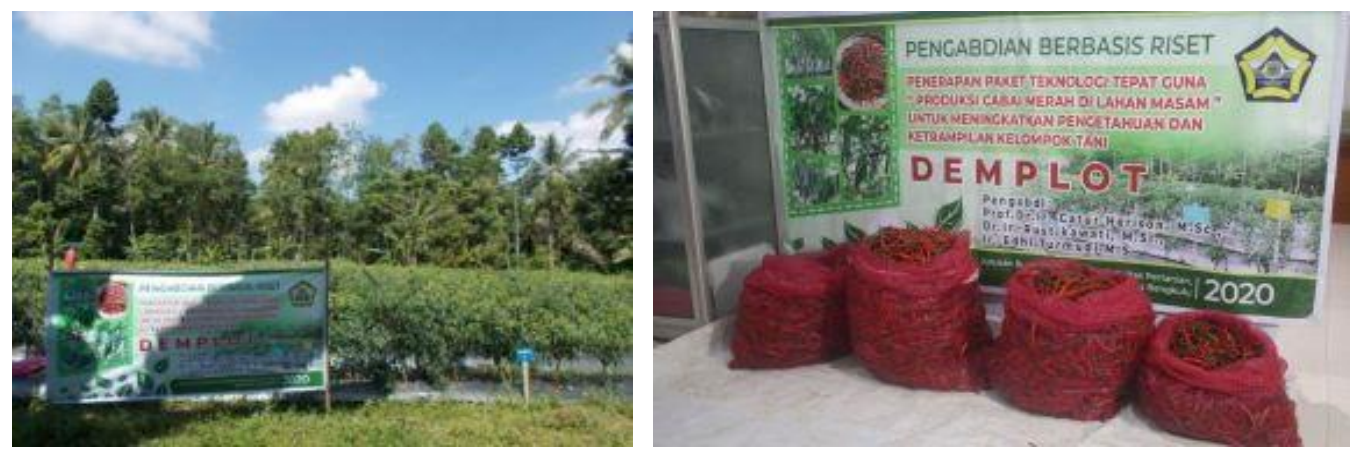

Gambar 6. Kondisi pertanaman (kiri) pada hasil (kanan) pada panen kelima

Kelarutan aluminium yang tinggi pada tanah kering masam membatasi ketersediaan unsur hara lain dan dapat menimbulkan keracunan bagi tanaman. Kondisi tersebut menyebabkan pertumbuhan dan hasil tanaman yang diusahakan umumnya rendah (Dalimunthe et al., 2015).

Upaya untuk mengatasi persolaan lahan masam dapat dilakukan melalui perbaikan potensi genetik tanaman dan manipulasi lingkungan melalui pengunaan kapur, pupuk kandang, pupuk anorganik dan bakteri pelarut fosfat. Beberapa peneliti telah melakukan penelitian, manipulasi lingkungan dengan penggunaan pupuk organik, kapur dan pupuk dalam produksi tanaman cabai (Ayodele \& Shittu, 2014; Setiawan, et al., 2016). Hasil penelitian pada Ultisol di wilayah Bengkulu menunjukkan bahwa teknologi terbaik untuk hibrida cabai merah adalah dolomit 2 ton/ha, pupuk kandang sapi 20 ton/ha, urea 400 $\mathrm{kg} / \mathrm{ha}$, SP36 $300 \mathrm{~kg} / \mathrm{ha}$ dan $150 \mathrm{~kg} / \mathrm{ha}$ secara fertigasi, pada jarak tanam $50 \mathrm{~cm}$ x $40 \mathrm{~cm}$ (Herison, et al., 2019). Hasil tersebut ditambahkan untuk melengkapi praktek budidaya yang sudah umum digunakan, seperti pengolahan lahan, penggunaan mulsa, pengelolaan organisme pengganggu, pemeliharan, panen dan pascapanen, menjadi suatu rumusan Paket Teknologi 'Produksi Cabai Merah di Lahan Masam'.

Kegiatan pemberdayaan petani melalui penyuluhan, praktek dan demonstransi plot penerapan Paket Teknologi 'Produksi Cabai Merah di Lahan Masam' merupakan salah satu cara yang dapat digunakan untuk menjawab permasalahan yang dihadapi petani. Harapannya adalah dengan meningkatnya pengetahuan dan ketrampilan, petani dapat meningkatkan 
produktivitas tanamannya di lahan masam dan pendapatannya.

Kegiatan pelatihan melalui penyuluhan, praktek dan demonstransi plot merupakan bentuk pendidikan informal yang menganut prinsip-prisip pendidikan orang dewasa karena belajar untuk menjawab masalah yang dihadapi petani. Kegiatan pelatihan yang telah dilakukan di kelompok tani Bangun Jaya dan Melati Mekar Bersama memperlihatkan terjadi peningkatan pengetahuan dalam pengelolaan lahan masam dan teknik budidaya cabai merah secara intensif. Pengalaman yang sama juga diperoleh Wardah et al. (2019) bahwa kegiatan pemberdayaan petani cabai berhasil meningkatkan pengetahuan, keterampilan, dan sikap peserta dari indikator yang dinilai. Kegiatan serupa dapat meningkatkan pendapatan keluarga melalui penghematan pengeluaran rumah tangga. (Nengsih et al., 2019).

\section{Kesimpulan}

Pengabdian penerapan paket teknologi budidaya cabai di lahan ultisol dapat meningkatkan pengetahuan petani dalam pengelolaan lahan masam dan teknik budidaya cabai merah secara intensif di lahan ultisol.

\section{Pengakuan/Acknowledgements}

Penulis mengucapkan terimakasih kepada Universitas Bengkulu yang telah mendanai kegiatan pengabdian melalui program Pengabdian Berbasis Riset Tahun 2020 melalui dana PNBP LPPM-UNIB dengan nomor kontrak: 2381/UN30.15/AM/2020. Kepada Kelompok Tani Bangun Jaya dan Kelompok Tani Melati Mekar Bersama juga diucapkan terima kasih atas kesediaannya sebagai mitra dalam pelaksanaan PPM ini. Terima kasih juga disampaikan kepada para mahasiswa Ulfa Husna, Zaki Febrian Anugrah, dan Ronaldi Antoni atas bantuanya dalam pelaksanaan penyuluhan dan demplot.

\section{Daftar Referensi}

Ayodele, O. J., \& Shittu. O.S. (2014). Fertilizer, Lime and Manure Amendments for Ultisols Formed on Coastal Plain Sands of Southern Nigeria. Agriculture, Forestry and Fisheries 3(6): 481-488. 
Dalimunthe, S.R., Arif, A.B \& Jamal, I.B. (2015). Uji Ketahanan terhadap Aluminium dan $\mathrm{pH}$ Rendah pada Jagung (Zea Mays L) Varietas Pioneer dan Srikandi Secara in Vitro." Jurnal Pertanian Tropik 2(3): 292-99.

Harnisah, S.E. Edi, I.K.W \& Honorita,B. (2016). Kinerja Model Kawasan Rumah Pangan Lestari (M-KRPL) di Kota Palembang. Prosiding Seminar Nasional Lahan Suboptimal

Herison, C., Suharjo, U.K.J. \& Handajaningsih, M. 2019. Rekayasa Teknologi Budidaya untuk Optimalisasi Produksi Hibrida Cabai Merah Unggul di Lahan Ultisol. Laporan Kemajuan 1 Penelitian Terapan. Bengkulu: Universitas Bengkulu.

Khotimah, H., Sumardi \& Handajaningsih, M. (2019). Pengaruh Jenis dan Dosis Pupuk Kandang Terhadap Pertumbuhan Dan Hasil Mentimun Jepang Di Ultisols. Skripsi, Bengkulu: Universitas Bengkulu. http://repository.unib.ac.id/20174/.

Nengsih, Y., Hartawan, R., \& Marpaung, R. (2019). Meningkatkan pola pangan harapan masyarakat desa betung melalui pemberdayaan masyarakat Sakai Sambayan - Jurnal Pengabdian kepada Masyarakat $3(1): 18-26$

Novita, D. D., \& Rahmawati, W. (2020). Pemberdayaan Wanita Tani Dalam Usaha Produksi Abuca (Abon dan Bubuk Cabai) di Kecamatan Adiluwih Kabupaten Pringsewu Sakai Sambayan - Jurnal Pengabdian kepada Masyarakat 4(2):105-109

Purwanto, S., Gani, R. A., \& Suryani, E. (2020). Characteristics of Ultisols derived from basaltic andesite materials and their association with old volcanic landforms in Indonesia. SAINS TANAH-Journal of Soil Science and Agroclimatology, 17(2), 135-143. http://dx.doi.org/10.20961/stjssa.v17i2.38301

Setiawan, J.A., Maghfoer, M.D. \& E. Nihayati. 2016. Application of Manure, Nitrogen Fertilizer, and EM4 to Improve Growth and Yield of Red Chili (Capsicum Annuum L) on an Alfisol. Journal of Degraded and Mining Lands Management 3(2): 535.

Tarihoran, R.P.A. (2013). Evaluasi Sumber Daya Lahan Untuk Pengembangan Pertanian Di Kecamatan Muara Bangka Hulu. Skripsi, Bengkulu: Fakultas Pertanian UNIB.

Wardah, E., Maisura, \& Budi, S. (2019). Dampak pelatihan pembuatan pupuk 
bokashi untuk petani cabai merah, Jurnal AGRIFO 4(2):87-92

Yanti, D.W. (2019). Respon Lima Genotipe Hibrida Cabai Merah (Capsicum Annuиm L.) Terhadap Beberapa Dosis Pupuk Kandang Sapi Di Ultisol. Skripsi. Fakultas Pertanian. Universitas Bengkulu. http://repository.unib.ac.id/19839/. 